\title{
Feasibility Study for a Solar PV Microgrid in Malawi
}

\author{
Aran Eales \\ dept. Electronic and \\ Electrical Engineering \\ University of Strathclyde \\ Glasgow, UK \\ aran.eales@strath.ac.uk
}

\author{
Lloyd Archer \\ Sustainable Energy \\ Management Unit \\ United Purpose \\ Blantyre, Malawi \\ lloyd.Archer@united- \\ purpose.org
}

\author{
Hannah Buckland \\ dept. Electronic and Electrical \\ Engineering \\ University of Strathclyde \\ Glasgow, UK \\ hannah.buckland@strath.ac.uk
}

\author{
Damien Frame \\ dept. Electronic and \\ Electrical Engineering \\ University of Strathclyde \\ Glasgow, UK \\ damien.frame@strath.ac.uk
}

\author{
Stuart Galloway \\ dept. Electronic and \\ Electrical Engineering \\ University of Strathclyde \\ Glasgow, UK \\ Stuart.galloway@strath.ac.uk
}

\begin{abstract}
Energy is an enabler for development but electricity access is still unobtainable for over 1 million people in developing countries. In Malawi, less than $12 \%$ of the population have access to grid electricity and in rural areas this is as low as $1 \%$. Solar microgrids are emerging as a cost competitive, low carbon and reliable method for offering energy access in developing countries. This paper provides a summary of the process and key findings in assessing technical and financial feasibility of a solar microgrid in Malawi, including system design definition, business model discussion and sensitivity analysis of key parameters through techno-economic modelling. The novel approach developed utilises qualitative and quantitative information gathering and assessment in an iterative way to design a robust energy access solution in the most viable local location. The results show that the upper limit of the 'expected energy use' can be up to 5 times higher than the designed energy limit. Higher demand grids are shown to present $\mathbf{c} .20 \%$ lower levelised cost of energy for the cases considered and conversely, the 'low demand' grid case is shown to have c. $48 \%$ higher levelised cost of energy . This represents a significant range of uncertainly in energy use prediction, which if not treated properly will adversely affect both energy access and microgrid business development. The research presented in this paper will address these challenges in the context of Malawi but is broadly applicable to other similar locations.
\end{abstract}

Keywords-Microgrid, Solar PV, Rural Electrification, Malawi

\section{INTRODUCTION}

Energy is the golden thread that connects economic growth, social equity and environmental sustainability [1]; however, secure access to modern electricity is lacking for over 1 billion people in the world [2]. This challenge is being addressed by the United Nations Sustainable Energy for All initiative [3], but the problem inherently demands new and innovative solutions for rural electrification. As shown in Figure 1, it is estimated that off-grid solutions are necessary to supply $40-63 \%$ of the additional generation needed in developing countries to achieve universal electricity access by 2030 [4]. Mini-grids, microgrids and nanogrids, defined as a set of electricity generators and energy storage systems interconnected to a distribution network supplying electricity to a localised group of customers [5], are proving to be a viable solution for rural (and peri-urban) areas unlikely to receive grid connection in the near future. This paper refers to the term 'microgrid' as systems below $10 \mathrm{~kW}$ but above $1 \mathrm{~kW}$ of rated generation capacity.

The microgrid market is on the rise globally, due in part to decreasing costs of renewable energy technologies, specifically solar PV modules and battery storage [6]. Increasing numbers of solar microgrid installations are being observed in East Africa with companies such as PowerGen [7] MeshPower [8] and SteamaCo [9] advancing innovation in technology for microgrid

This study was commissioned by United Purpose Malawi through the Irish Aid funded ACCESS programme. metering, monitoring and control as well as business models and tariff setting.

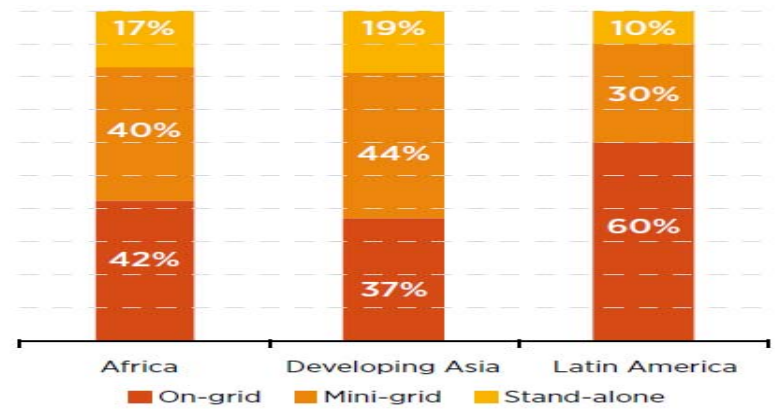

Fig. 1. Additional generation needed for universal electricity access by 2030 (by region and source) [4].

Malawi's is one of the poorest countries in the world with economic development and poverty reduction efforts limited due to low levels of electrification, especially in rural areas [10]. Malawi's electricity use per capita is $85 \mathrm{kWh}$ compared with $169 \mathrm{kWh}$ in eastern Africa, with an electricity access rate of $11.9 \%$ in 2014 [11]. With the mentioned cost reductions in solar PV components coupled with high solar resource, there has been increasing interest in implementing solar PV microgrids in Malawi, especially in areas unlikely to receive a main grid connection in the near future. Given the high percentage of population currently unserved by the national grid, the potential market for solar microgrids is large. The scale of microgrids addresses a gap in the market, fulfilling a niche that offers higher levels of access than solar home systems or pico solar products, but with lower capital costs than current $>80 \mathrm{~kW}$ mini-grid systems being installed in Malawi [12]. The market potential for small, densely populated villages more than $5 \mathrm{~km}$ from a grid connection in Malawi is estimated to be over 4.5 million, or $27 \%$ of the population [13].

TABLE I. Grid Connection Statistics For Malawi [13]

\begin{tabular}{|c|c|c|c|}
\hline $\begin{array}{c}\text { Population } \\
\text { density }\end{array}$ & $\begin{array}{c}\text { Population } \\
\text { living }<\mathbf{5 k m} \\
\text { from MV line }\end{array}$ & $\begin{array}{c}\text { Population } \\
\text { living }>\mathbf{5 k m} \\
\text { from MV line }\end{array}$ & Total \\
\hline$<\mathbf{2 5 0 h a b} / \mathbf{k m}^{\mathbf{2}}$ & $\begin{array}{c}2,285,822 \\
(14 \%)\end{array}$ & $\begin{array}{c}4,508,842 \\
(27 \%)\end{array}$ & $6,794,664$ \\
& $5,437,076$ & $4,545,807$ & $(40 \%)$ \\
\hline$>=\mathbf{2 5 0 h a b} / \mathbf{k m}^{2}$ & $(32 \%)$ & $(27 \%)$ & $(60 \%)$ \\
\hline Total & $7,722,898$ & $9,054,649$ & $16,777,547$ \\
& $(46 \%)$ & $(54 \%)$ & \\
\hline
\end{tabular}

With few existing microgrid initiatives in developing countries, and none in Malawi, there is clear motivation for robust research work in this area. On this basis, this paper assesses technical and financial feasibility of the emerging microgrid technologies in Malawi: Section II outlines a brief 
methodology, while Section III defines the system design. The business model is described in Section IV including finance considerations, while techno-economic modelling on sensitivity values is described in Section V, before drawing conclusions in Section VI.

\section{METHODOLOGY OVERVIEW}

The proposed method for system design and business planning builds on industry standards [14], [15] and employs two key elements: a qualitative site selection and customer survey exercise, utilising enumerator fieldwork to provide metrics for project feasibility; and a quantitative techno-economic modelling, focussing on technical and financial feasibility to inform a viable business model. The two tasks comprise a cyclic iterative process, allowing for anecdotal information and more quantifiable information to be assessed simultaneously.

The site selection exercise scores potential villages in the Dedza district of Malawi based on strategic indicators such as distance to grid, population density, accessibility and economic activities. Structured questionnaires (targeted to households and businesses in the chosen site) input into key system design metrics and include indicators such as: current and expected energy use estimation, ability and willingness to pay, existing and aspirational businesses activity and other informative social and demographic indicators. Data collection utilises digital data collection platform kobocollect [16] via trained enumerators. Data analysis informs system component specification (size and cost) and assists in business model exploration towards financial viability. Alongside survey data gathering, techno-economic modelling is carried out using the software tool HOMERPro, allowing for quantitative review of financial and technical feasibility. By combining the quantifiable elements of microgrid development with invaluable fieldwork and local knowledge, a more robust and informed solution is found for local electrification.

\section{SYSTEM DESIGN}

Component specifications are calculated with input parameters of load profiles and renewable energy resources following Malawian electrical design standard methods. The output is an indicative system design with component specifications, grid architecture, controls, and associated cost to inform the business model.

\section{A. Load Profiles}

Accurate load characteristics (both current and expected) are essential to inform microgrid power generation system design and financial modelling. The energy demand is given by the sum of the products of appliance power and the hours of use, and is represented as:

$$
D=\sum_{i=0}^{n} h W_{i}
$$

Where $D$ is total demand in $\mathrm{kWh}, h$ is the duration of operation of the appliance in hours and $W_{\mathrm{i}}$ is the wattage of the i-th appliance. To account for future energy use uncertainty, this methodology models three different load profile scenarios based on existing and 'aspirational' energy use of the village (derived from demand survey analysis). Productive uses of energy such as lighting, refrigeration and barbershops were deemed high priority by survey respondents, as were household connections for domestic lighting and phone charging. Table I shows total daily energy consumption based on appliance use for different customer segments.

TABLE I: Appliance and total daily energy by customer segment

\begin{tabular}{|c|c|c|c|c|c|c|c|c|c|}
\hline $\begin{array}{c}\text { Customer } \\
\text { Segment }\end{array}$ & 尝 & 氙 & 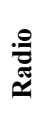 & $\Xi$ & 2 & 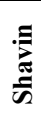 & 象 & 范 & 류류 \\
\hline $\begin{array}{l}\text { Household - low } \\
\text { income }\end{array}$ & * & $*$ & $*$ & & & & & & $62 \mathrm{Wh}$ \\
\hline Grocery Shop & $*$ & $*$ & $*$ & & & & & & $165 \mathrm{Wh}$ \\
\hline $\begin{array}{l}\text { Household - high } \\
\text { income }\end{array}$ & $*$ & $*$ & $*$ & & $*$ & & & & $302 \mathrm{Wh}$ \\
\hline Barber Shop & $*$ & $*$ & $*$ & $*$ & & $*$ & & & $540 \mathrm{Wh}$ \\
\hline Video Show & $*$ & $*$ & $*$ & & * & $*$ & $*$ & & $1225 \mathrm{Wh}$ \\
\hline $\begin{array}{l}\text { Grocery Shop } \\
\text { Fridge and Fan }\end{array}$ & $*$ & $*$ & $*$ & $*$ & & & & * & $1605 \mathrm{Wh}$ \\
\hline
\end{tabular}

Varying quantities of each customer segment enables modelling for low use, expected use and high use demand scenarios. The calculated load profiles were compared to measured load profiles from equivalent solar microgrids in existing literature [17], [18] to validate. The load profile for the expected use scenario, shown in Figure 2, indicates that demand is predicted to peak in the evening. Figure 3 shows the low demand and high demand scenarios compared to expected use. Between 0 and 6 am the large spikes correlate to cyclic loads from fridges running without other energy uses. The high demand scenario can be up to 5 times higher than expected use, highlighting the large levels of uncertainty and difficulty in predicting energy use for such behaviour changing energy provision..

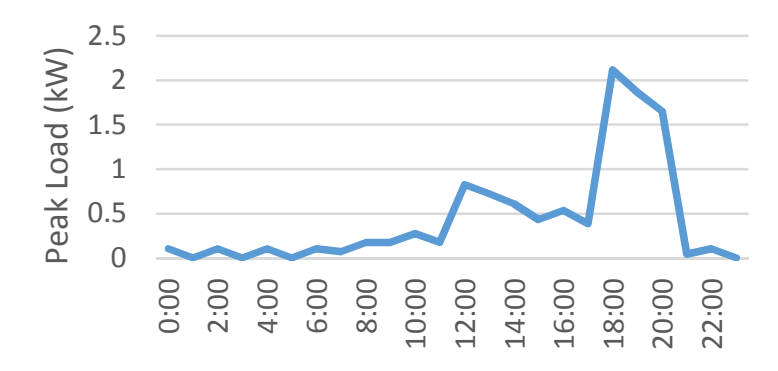

Fig. 2. Load profile for expeted use scenario

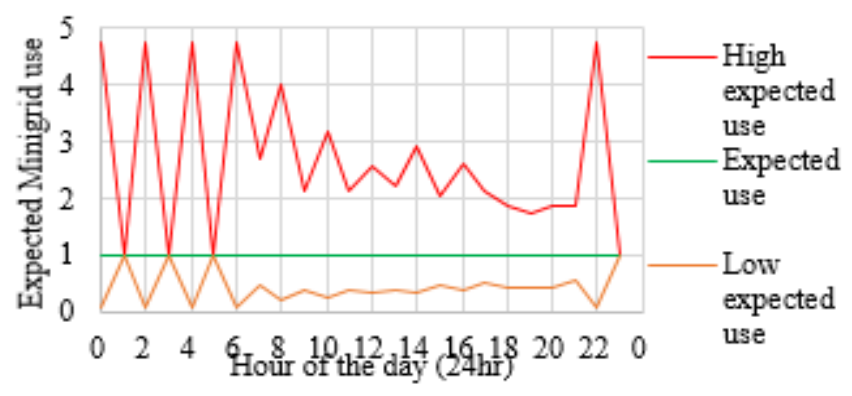

Fig. 3. High and low useage limits normalised against expected use 


\section{B. Solar Resource}

Solar resource data from NASA surface meteorology and Solar Energy, global horizontal radiation, monthly averaged values over 22 year period (July 1983 - June 2005) [19] were used for system design and modelling. The solar resources data for the modelling utilised a comprehensive data set based on satellite and meteorological modelling, validated by ground measurements. Figure 4 is the resource input data, a scaled annual average of $5.33 \mathrm{kWh} / \mathrm{m}^{2} /$ day was used with low and high sensitivities of $5.02 \mathrm{kWh} / \mathrm{m}^{2} /$ day and $6.42 \mathrm{kWh} / \mathrm{m}^{2} /$ day respectively used to investigate seasonal solar variation.

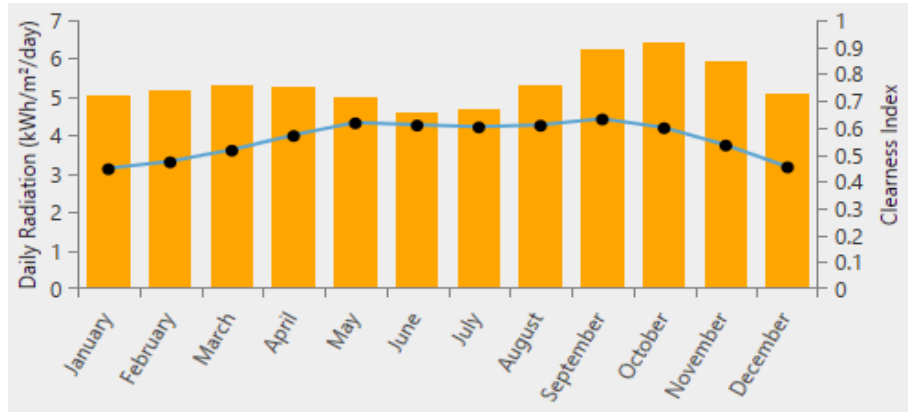

Fig. 4. Seasonal average daily radiation and clearness index

\section{Component Specification and Costs}

The microgrid system consists of 'central generation' comprising a PV array, battery storage, inverter and auxiliary components, providing a service of wired AC electrical connection through a distribution grid. A smart-meter solution allows for customers to purchase pre-paid per $\mathrm{kWh}$ tariffs via a local vendor. Once a customer's account runs out of funds, the system automatically engages a relay to halt supply until a topup is received.

GPS coordinates of the demand surveys were plotted using GIS software and used to represent potential microgrid customer locations. An indicative distribution and supply network was then mapped to obtain cable lengths and associated sizes for allowable voltage drop. A schematic for the microgrid is displayed in Figure 5.

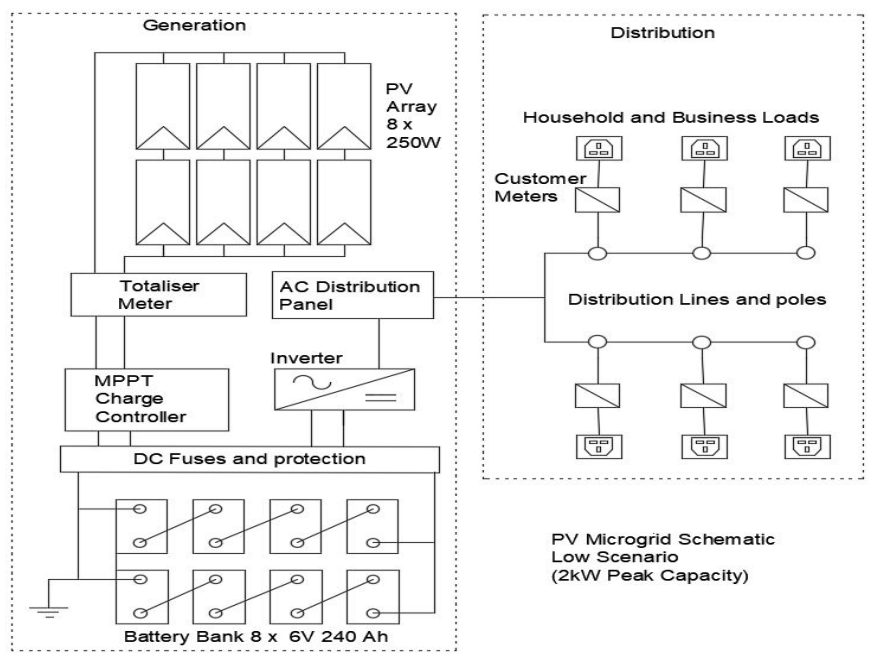

Fig. 5. Schematic for the small $(2 \mathrm{kWp})$ microgrid
A 'bill of quantities' is created to obtain quotes from reputable suppliers of solar PV equipment in Malawi for all system components. These system costs are added to benchmark values for 'softer costs' such as site selection, project development, and community sensitisation to estimate initial capital expenditure (CAPEX) for the three modelled scenarios. The component specifications for the three system sizes are outlined in Table II, and system costs and CAPEX are discussed in section IV. The presented data is then utilised for business financial modelling.

TABLE II. COMPONENT SPECIFICATIONS FOR MICROGRID SCENARIOS

\begin{tabular}{|c|c|c|c|}
\hline & Small Grid & $\begin{array}{l}\text { Expected } \\
\text { Use Grid }\end{array}$ & $\begin{array}{c}\text { Large } \\
\text { Grid }\end{array}$ \\
\hline Battery specifications & \multicolumn{3}{|c|}{$\begin{array}{c}6 \mathrm{~V}, 240 \text { Ah Victron AGM Lead Acid } \\
\text { Batteries, } \\
\end{array}$} \\
\hline Number of Batteries & 8 & 24 & 40 \\
\hline Battery Capacity (kWh) & 11.52 & 34.56 & 57.6 \\
\hline PV specifications & \multicolumn{3}{|c|}{$\begin{array}{c}\text { Monocrystalline, } 250 \mathrm{~W}, 30.49 \mathrm{~V} \\
8.2 \mathrm{~A} ; \mathrm{Isc}=8.78 ; \mathrm{Voc}=38 \mathrm{~V} \text { Jinko } / \mathrm{JA}\end{array}$} \\
\hline PV Array Size (kW) & 2 & 4.5 & 10 \\
\hline Inverter Size (kVA) & 2 & 4 & 8 \\
\hline Charge Controller Rating (A) & 44 & 99 & 219 \\
\hline
\end{tabular}

\section{MiCROGRID BUSINESS MODEL}

The business model canvas is an open source strategic management and entrepreneurial tool developed by online business advisor Strategyzer, used to design and pilot business models [20]. It is utilised in this work to outline important parameters such as key resources, cost structure and revenue streams for the proposed microgrid business. The framework is a useful planning tool for in-country practitioners to map business activities and an essential basis for a sustainable business model. The full business canvas is outside the scope of this paper, however the value proposition is outlined below, followed by key parameters for business feasibility, namely ability and willingness to pay, tariff setting and business finance.

\section{A. Value Proposition for a Solar Microgrid}

The intention with the microgrid development is to offer value to the community in the supply of a safe, affordable and reliable electrical connection (supplying of the order of 100 customers) improving quality of life at a domestic level and offering an opportunity for local income development for businesses. The provision of electricity to the community aims to spur economic growth, attract investment for business and provide employment in an area which is currently underdeveloped. Microgrid businesses maintained and managed through a social enterprise framework provides positive impacts on project sustainability. Household electricity will provide opportunities for evening study for school going children increasing child literacy, increased security and increased social opportunities [21]. Charging phones in the house will remove the need to travel to the grid, as well as cost savings in paying to charge. It is found that the cost of accessing power through the microgrid by individual households is relatively cheaper compared to current energy use, helping project beneficiaries to save money for other uses. 


\section{B. Ability and Willingness to Pay}

Determining the ability and willingness to pay (ATP) of customers is inherently difficult, but essential for setting tariffs and business planning [15]. Section III highlighted high levels of uncertainty in expected electricity demand, particularly for previously unconnected communities. In addition, considerable variation can exist between relative wealth levels in rural villages. Several indicators for ATP based on demand surveys were compared with cost reflective tariffs: the average monthly income figures for the village are shown in Table III, while a description of indicators used for household willingness to pay are shown in Table IV. Monthly incomes range between approximately $\$ 22$ to $\$ 27$ and it can be seen that around $10-30 \%$ of that income is spent on energy. The ability to set tariffs equating to existing monthly energy spends or less is an essential measure of feasibility.

TABLE III. MEAN AND MEDIAN MONTHLY INCOME IN THE VILLAGE IN MALAWI KWATCHA (MWK) AND US DOLLARS

\begin{tabular}{|c|c|c|c|c|}
\hline & $\begin{array}{c}\text { Agricultural } \\
\text { (MWK) }\end{array}$ & $\begin{array}{c}\text { Non-agricultural } \\
\text { (MWK) }\end{array}$ & $\begin{array}{c}\text { TOTAL } \\
\text { (MWK) }\end{array}$ & $\begin{array}{c}\text { TOTAL } \\
\text { (USD) }\end{array}$ \\
\hline MEAN & 18,143 & 2,077 & 20,220 & $\$ 27.30$ \\
\hline MEDIAN & 12,500 & 1,250 & 16,667 & $\$ 22.50$ \\
\hline
\end{tabular}

TABLE IV. ABILITY AND WILLINGNESS TO PAY INDICATORS

\begin{tabular}{|c|c|c|}
\hline Description of indicator & MWK & USD \\
\hline Household monthly energy spend (from surveys) & 3,648 & $\$ 5.11$ \\
\hline $\begin{array}{c}\text { Household average monthly spend on dry cell batteries } \\
\text { plus monthly phone charging costs }\end{array}$ & 2,228 & $\$ 3.12$ \\
\hline $\begin{array}{c}\text { Average answer to question "What would you be willing } \\
\text { to pay per month for lighting and phone charging in your } \\
\text { house?" 15\% subtracted based on evidence from existing } \\
\text { microgrid initiatives [22] }\end{array}$ & 4,836 & $\$ 6.77$ \\
\hline
\end{tabular}

\section{Tariff Setting}

The average tariff for all customer segments is calculated by dividing the total revenue by billed consumption. Revenue requirement includes operation and maintenance costs (OPEX) for generation and distribution plus sales and administration costs for the business. Cost reflective tariffs calculated for each scenario are then compared to customer willingness and ability to pay. Figure 6 illustrates the cost and energy components of tariff calculations, while Table $\mathrm{V}$ describes in detail the tariff parameters.

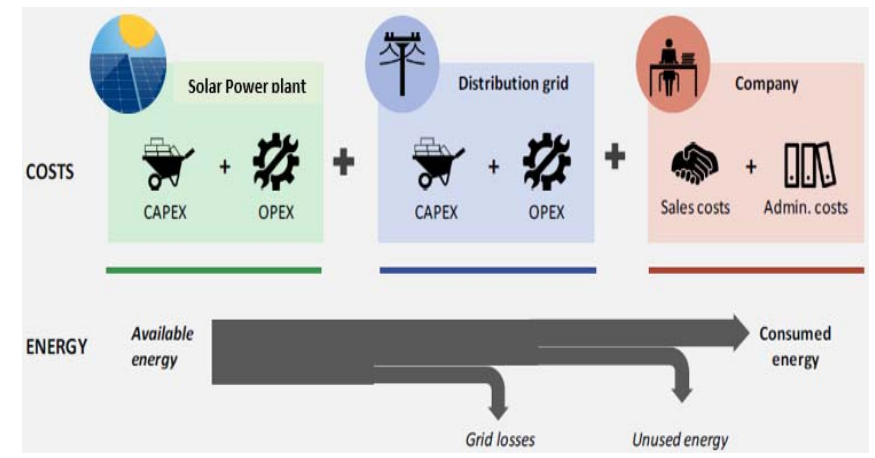

Fig. 6. Cost and Energy considerations for tariff setting adapted from [23]
TABLE V. PARAMETER DESCRIPTIONS FOR CALCULATING TARIFFS [24]

\begin{tabular}{|c|c|}
\hline Parameter & Information required and parameter assuptions \\
\hline $\begin{array}{l}\text { Operating } \\
\text { costs }\end{array}$ & Requires estimation of annual costs for the tariff period \\
\hline Capital costs & Upfront costs required to install the grid \\
\hline Depreciation & $\begin{array}{l}\text { Calculated by first determining the opening asset value for } \\
\text { each asset type in each year, and dividing by the asset life }\end{array}$ \\
\hline $\begin{array}{c}\text { Return on } \\
\text { capital }\end{array}$ & $\begin{array}{l}\text { The rate of return offered to investors, based on weighted } \\
\text { average cost of capital (WACC) }\end{array}$ \\
\hline $\begin{array}{l}\text { Collections } \\
\text { rate }\end{array}$ & $\begin{array}{c}\text { Estimate what percentage of electricity delivered will be paid } \\
\text { for }\end{array}$ \\
\hline $\begin{array}{l}\text { Deductible } \\
\text { income }\end{array}$ & $\begin{array}{l}\text { Includes connection fees and other income not related directly } \\
\text { to the sale of electricity. }\end{array}$ \\
\hline $\begin{array}{c}\text { Billed } \\
\text { consumption }\end{array}$ & Assists in converting revenue requirement to an average tariff \\
\hline
\end{tabular}

\section{Business Finance}

Figure 7 shows CAPEX by category and it is evident that distribution costs are highest in each case ${ }^{1}$. Expected CAPEX is double the low CAPEX case (a system designed for the low use descried in Figure 3). However, the high CAPEX case is less than double expected CAPEX, even more surprising considering the 'high use' case can (at times) support 5 times the load as the expected use case, as shown in Figure 3.

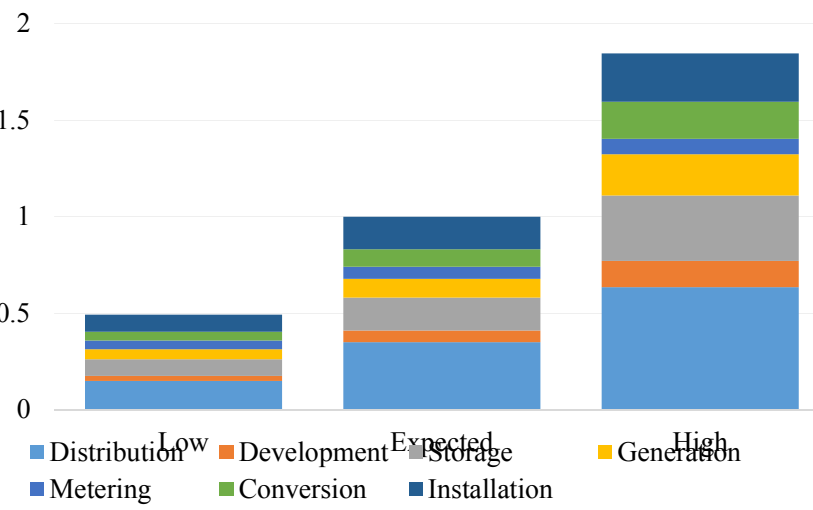

Fig. 7. CAPEX by category, normalised by expected total CAPEX.

Table VI shows that CAPEX per customer of the modelled grids is $\$ 895-\$ 1,208$, and annual OPEX ranges from about $\$ 2,000$ to $\$ 6,000$ per year. Generally, electricity can be sold cheaper and cash flow increases as the size of the grid increases, with tariffs decreasing from $\$ 2.03 / \mathrm{kWh}$ to $\$ 1.22 / \mathrm{kWh}$ from the small to large grids respectively. Cost reflective tariffs compared favourably to the ability and willingness to pay of the village, with the larger grids offering cheaper more affordable tariffs.

TABLE VI. Key Microgrid FinANCIAL PARAMETERS

\begin{tabular}{|c|c|c|c|}
\hline & $\begin{array}{c}\text { Small Grid } \\
(\mathbf{2 . 5 k W p )}\end{array}$ & $\begin{array}{c}\text { Medium Grid } \\
\mathbf{( 4 . 5 k W p )}\end{array}$ & $\begin{array}{c}\text { Large Grid } \\
(\mathbf{1 0 k W p})\end{array}$ \\
\hline $\begin{array}{c}\text { CAPEX per } \\
\text { customer }\end{array}$ & $\$ 895$ & $\$ 976$ & $\$ 1,208$ \\
\hline Annual OPEX & $\$ 2,060$ & $\$ 3,863$ & $\$ 6,215$ \\
\hline $\begin{array}{c}\text { Initial Cost } \\
\text { Reflective } \\
\text { Tariff }\end{array}$ & $\$ 2.03 / \mathrm{kWh}$ & $\$ 1.56 / \mathrm{kWh}$ & $\$ 1.22 / \mathrm{kWh}$ \\
\hline $\begin{array}{c}\text { Total Net } \\
\text { Present Cost }\end{array}$ & $\$ 60,707$ & $\$ 126,921$ & $\$ 149,238$ \\
\hline
\end{tabular}

\footnotetext{
${ }^{1}$ The authors suspect that this is due to Malawian microgrid installers providing conservative quotes due to inexperience with these types of projects
} 
Three key financial statements for each microgrid scenario are compiled, namely: Income Statement, Cash Flow and Balance Sheet. The consolidated results for each microgrid include profit and loss calculation resulting in Earnings Before Interest, Taxes, Depreciation and Amortization, The final output is Annual Net Income, cumulated for high level comparison.

A $100 \%$ grant model was assumed as a realistic case for this analysis, investigating each grid scenario with CAPEX fully funded to consider how using tariffs that are centred around 'ability to pay' effects the Cashflows. The Cashflow is considered against CAPEX, to give an indication as to how long it will take the grid to accumulate enough income to enable the CAPEX of another grid the same size. It was found that the small grid case is the least feasible, with the income over 20 years never reaching required CAPEX levels for a new grid. The medium grid case reaches the threshold in year 20, while the large grid case makes it in year 16 .

\section{TECHNO-ECONOMIC MODELLING}

Energy systems modelling software HOMERPro has been utilised using the assumptions and data presented above to explore sensitivity of uncertain values. Specifically, the Levelised Cost of Energy (LCOE) ( $\$ / \mathrm{kWh})$ and Net Present Cost (NPC) can be calculated for each scenario and used as indicators for sensitivity analysis, allowing insight to which parameters affect the grid most acutely.

\section{A. Net Present Cost and Levelised Cost of Energy}

The NPC of a system is the present value of all the costs of installing and operating the system over the project lifetime, minus the present value of all the revenues that it earns over the project lifetime. The LCOE is defined as the average cost per $\mathrm{kWh}$ of useful electrical energy produced by the system.

Table VII outlines the NPC and LCOE of all three systems modelled, with all sensitivity values set at the middle value, representing a likely situation. The LCOE figures are comparable to benchmark results [25], [26]. The figures are similar to the cost reflective tariffs calculated above, but use a different method taking into account discount rate. The larger usage grids are shown to present a c. $20 \%$ lower LCOE for the cases modelled in this study. Conversely, the 'low usage' grid case is shown to have a c. $48 \%$ higher LCOE.

\begin{tabular}{|c|c|c|c|}
\hline & Small Grid & Medium Grid & Laroe Grid \\
\hline Total NPC & $\$ 60,707$ & $\$ 126,921$ & $\$ 149,238$ \\
\hline LCOE & $\$ 2.44 / \mathrm{kWh}$ & $\$ 1.64 / \mathrm{kWh}$ & $\$ 1.33 / \mathrm{kWh}$ \\
\hline
\end{tabular}

\section{B. Project Lifetime Sensitivity}

Figure 8 shows the effect of project lifetime sensitivity. A LCOE saving of $\$ 0.4 / \mathrm{kWh}$ (falling from $2.1 / \mathrm{kWh}$ to $1.7 / \mathrm{kWh}$ ) can be achieved by extending the project lifetime from 15 to 25 years. Keeping a project going through regular maintenance is obviously desirable, however given sustainability challenges of off grid systems in Malawi [27] a 25 year lifetime is considered highly optimistic.

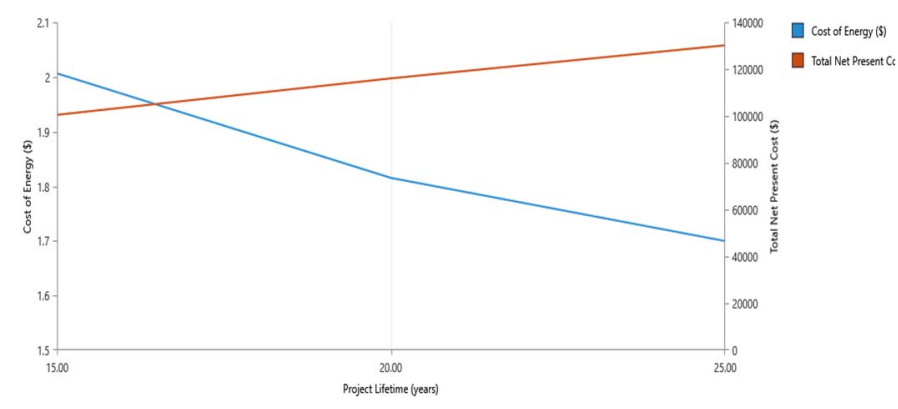

Fig. 8. Effect of Project Lifetime on COE and NPV

\section{Solar Resource and Temperature Sensitivty}

Figure 9 shows the effect of the range of solar resources and temperatures that can be expected at the chosen site. The solar resource has more of an effect on LCOE than temperature; however, the maximum difference between all values of temperature and solar resource is $0.02 / \mathrm{kWh}$, demonstrating the geographical constraints have little effect on the LCOE of the system. This suggests that the approach presented in this paper can be usefully transferred to other locations in Malawi.

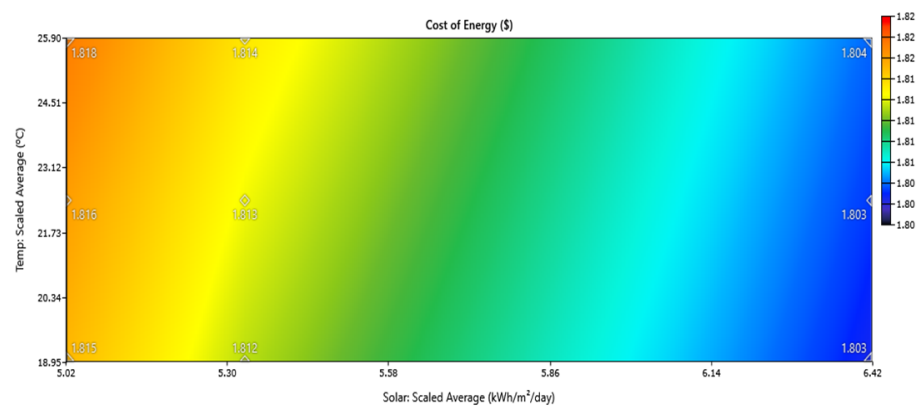

Fig. 9. Effect of solar resource and temperature on $\mathrm{COE}$

\section{Load Growth Sensitivty}

A $5 \%$ load growth was assumed over the 20 -year project period, with daily energy demand increasing at 5 year intervals input as sensitivities for HOMER. Figure 10 shows the effect of a $5 \%$ load growth on the NPC and LCOE. While a modest increase in NPC is observed $(\$ 116,100$ to $\$ 153,449)$, a significant reduction in LCOE is observed from $\$ 1.81 / \mathrm{kWh}$ down to $\$ 0.98 / \mathrm{kWh}$. Stimulating electricity demand is therefore key to reducing cost of energy, suggesting significant project effort and budget should be used for local information dissemination.

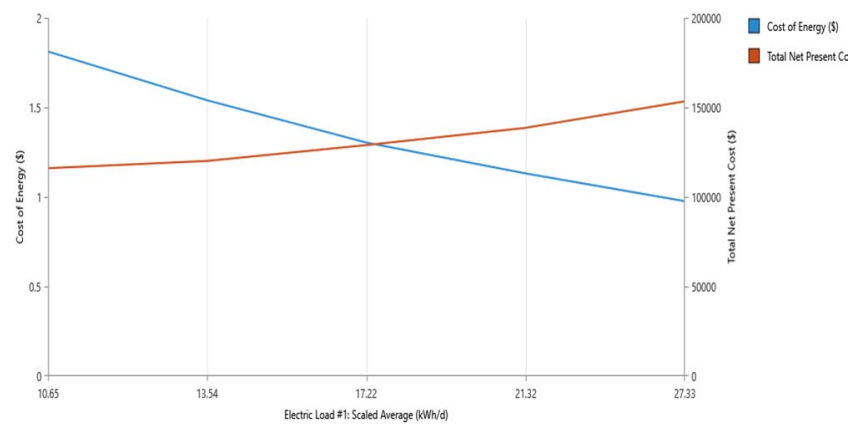

Fig. 10. Effect of Load Growth on LCOE and NPV 


\section{CONCLUSIONS}

A robust methodology has been described in detail to assess the feasibility of a solar microgrid in Malawi. As a pathway to rural electrification, microgrids offer a reliable and affordable solution, and (when managed as a social enterprise) have potential to ensure project sustainability. Of the scenarios modelled, the expected use $(4.5 \mathrm{~kW})$ and high use $(10 \mathrm{~kW})$ microgrids are found to be feasible in terms of affordability and cash flows. However, although larger grids take advantage of economies of scale, a conservative view on demand is recommended particularly for communities that do not have previous experience with electricity access. Sensitivity analysis revealed significant Cost of Energy reductions can be achieved through increasing demand and extending project life. Further research is being conducted to investigate the effect of financing of the microgrid, including equity and debt options for raising initial capital.

The microgrid sector in Malawi is in its infancy, making CAPEX costs slightly higher than benchmark studies; similarly the 'ability to pay' is likely to be lower in Malawi compared to existing initiatives in Kenya and Tanzania. Additional to the technical and economic parameters discussed here, it should be noted that further barriers exist in the Malawian minigrid ecosystem, which include an unfavourable regulatory system, access to finance, and gaps in human capacity for implementation. Nevertheless, progress is being made to realise the potential solar microgrid systems have for benefiting and transforming the lives of rural communities.

\section{REFERENCES}

[1] United Nations, "Secretary-General to Global Development Center: 'Energy is the Golden Thread' Connecting Economic Growth, Social Equity' | Meetings Coverage and Press Releases."

[2] I. - International Energy Agency, "WEO-2017 Special Report: Energy Access Outlook,” 2030.

[3] W. B. UNDP, "Sustainable Energy for All (SEforALL)." [Online]. Available: http://www.se4all.org/. [Accessed: 21-Jan-2018].

[4] IRENA, Innovation Outlook: Renewable Mini-Grids. 2016.

[5] "Mini Grids - energypedia.info." [Online]. Available: https://energypedia.info/wiki/Mini_Grids. [Accessed: 02-May2018].

[6] I. Renewable Energy Agency, "Solar pv in africa: costs and markets," 2016.

[7] "PowerGen" [Online]. Available: http://www.powergen-renewableenergy.com/. [Accessed: 02-May-2018].

[8] "MeshPower - Home." [Online]. Available: http://www.meshpower.co.rw/. [Accessed: 02-May-2018].

[9] “steama.co." [Online]. Available: http://steama.co/. [Accessed: 03Apr-2018].

[10] A. Eales, D. Frame, P. Dauenhauer, B. Kambombo, and P.
Kamanga, "Electricity access options appraisal in Malawi: Dedza district case study," in Proceedings - 2017 IEEE PES-IAS PowerAfrica Conference: Harnessing Energy, Information and Communications Technology (ICT) for Affordable Electrification of Africa, PowerAfrica 2017, 2017.

[11] World Bank, "CountryProfile | World Development Indicators."

[12] "Home / MEGA.” [Online]. Available: http://www.mega.mw/. [Accessed: 28-Mar-2018].

[13] Dfid, "Support Study for DFID Low Carbon Mini Grids \&quot; Identifying the gaps and building the evidence base on low carbon mini-grids \&quot; Final Report," 2013.

[14] T. German and C. Technology, "What size shall it be ?"

[15] T. Safdar, "Business models for mini-grids Smart Villages Business models for mini-grids," 2017.

[16] "KoBoToolbox | Data Collection Tools for Challenging Environments.” [Online]. Available: http://www.kobotoolbox.org/. [Accessed: 03-Apr-2018].

[17] N. J. Williams, P. Jaramillo, B. Cornell, I. Lyons-galante, and E. Wynn, "Load Characteristics of East African Microgrids," pp. 236241, 2017.

[18] C. Blodgett, P. Dauenhauer, H. Louie, and L. Kickham, “Accuracy of energy-use surveys in predicting rural mini-grid user consumption," Energy Sustain. Dev., vol. 41, pp. 88-105, Dec. 2017.

[19] NASA, "NASA Surface meteorology and Solar Energy: Global Data Sets." [Online]. Available: https://eosweb.larc.nasa.gov/cgibin/sse/global.cgi. [Accessed: 02-May-2018].

[20] Strategyzer, "The Business Canvas." [Online]. Available: https://strategyzer.com/. [Accessed: 03-Apr-2018].

[21] A. Eales, L. Walley, H. Buckland, D. Frame, and S. Strachan, "Social Impacts of Mini-grids : Towards an Evaluation Methodology," in Power Africa, 2018.

[22] C. Blodgett, E. Moder, L. Kickham, and H. Leaf, "Vulcan Impact Investing," 2016.

[23] L. Payen, M. Bordeleau, and T. Young, "Developing Mini-grids in Zambia: How to build sustainable and scalable business models?," pp. 1-37, 2016.

[24] Malawi Regulatory Authority, "Tariff Framework for Mini Grids in Malawi."

[25] World Bank, "Benchmarking study of solar pv mini grids investment costs ESMAP Mission," 2017.

[26] T. Reber, S. Booth, D. Cutler, X. Li, J. Salasovich, and W. Ratterman, "Tariff considerations for micro-grids in sub-saharan africa."

[27] D. Frame and P. Dauenhauer, "Sustainability of Solar PV Institutions in Malawi." 